\title{
Principles of follow-up assessments in patients with breast cancer after radical treatment
}

\author{
Diana Hodorowicz-Zaniewska', Krzysztof Herman² \\ ${ }^{1}$ Chair of Ceneral Surgery, Department of General, Oncological, and Gastrointestinal Surgery, Jagiellonian University Medical College, 40 Kopernika St., \\ 31-501 Krakow, Kierownik: prof. dr hab. Jan Kulig \\ ²Departament of Surgical Oncology, M. Skłodowska-Curie Memorial Institute of Oncology, 11 Garncarska St., 31-115 Kraków, Kierownik: prof. dr hab. Jerzy Mituś
}

Article history: Received: 22.03.2016 Accepted: 27.04.2017 Published: 30.06.2017

ABSTRACT: $\quad$ A follow-up assessment plan after radical treatment is a part of a comprehensive approach to treating patients with breast cancer. Because breast cancer is the most frequent cancer both worldwide and in Poland, adequate follow-up is important not only for patients but also for economic reasons.

Herein, we review current recommendations for follow-up assessments in patients with breast cancer. The main aim of such assessment is detection of early recurrence or tumor presence in the other breast, observation of long-term treatment complications, and creation of multidisciplinary infrastructure that will allow to reduce the risk of recurrence and alleviate physical, mental, and social consequences of treatment.

KEYWORDS: $\quad$ breast cancer, treatment follow-up, recommendations

In 2010, the American Society of Clinical Oncology (ASCO) published a list of the five most important and expensive practices in oncology (the so-called Top Five) that are used commonly despite the lack of evidence for their health-related benefits $(1,2)$. One of those practices was lack of compliance with the principles of follow-up assessments in patients with breast cancer.

A survey conducted among USA-based oncologists showed that $20-40 \%$ of them order additional studies that are not part of standard assessment (3-5). In Poland, despite the lack of such data, one can assume that the situation is similar. Responsibility for follow-up assessments should be assumed by the treating center, and in the Polish healthcare system it is shared by oncological and surgical institutions.

Breast cancer, being the most common cancer both worldwide and in Poland, constitutes a significant social issue. An increasing morbidity with constant mortality for several years (6) reflects the fact that breast cancer is treated successfully. Currently, the five-year survival rate in the USA and Western Europe is estimated at $85 \%$, and the ten-year survival rate at $70 \%(7,8)$. In Poland, these figures are lower by $10 \%$ (7), and tumor stage at diagnosis remains the most important prognostic factor. Total recurrence risk for patients who receive radical treatment is $10 \%$ (9), with $80 \%$ of all recurrence cases seen within 5 years of treatment, especially in the second year after diagnosis (10). It should be emphasized that it is not always clear if we deal with recurrence of a previously removed tumor or with a new tumor in the same breast. One thing that is peculiar to breast cancer is late local or systemic recurrence, after 10-20 years since diagnosis, which is observed in tumors positive for estrogen or progesterone receptors.

For that reason, follow-up assessments after radical treatment should be conducted throughout lifespan with an aim to early detect local recurrence and/or new tumor in the same or oth-
Tab. I. Evidence-based ranking of recommendations in clinical guidelines (13)

LEVEL OF MEDICAL EVIDENCE
$\begin{aligned} & \text { Evidence from at least one, large, randomized, controlled clinical trial } \\ & \text { or meta-analysis of homogenous randomized trials }\end{aligned}$
II $\quad \begin{aligned} & \text { Evidence from small, randomized trials or meta-analysis of } \\ & \text { heterogeneous randomized trials }\end{aligned}$
III $\quad$ Evidence from prospective cohort studies
IV $\quad$ Evidence from retrospective cohort studies or case-control studies
V $\quad \begin{aligned} & \text { Evidence from trials without control groups, descriptive studies, expert } \\ & \text { opinions }\end{aligned}$
STRENGTH of RECommENDATION
A $\quad \begin{aligned} & \text { Strong recommendation, evidence for a significant clinical benefit } \\ & \text { B }\end{aligned} \quad \begin{aligned} & \text { Strong recommendation but with lower certainty, probably true for } \\ & \text { most individual cases }\end{aligned}$
C $\quad \begin{aligned} & \text { Moderate recommendation, can be changed based on more reliable } \\ & \text { data; probably true, insufficient evidence for clinical efficacy, }\end{aligned}$
facultative recommendation

er breast. It is also important to assess for long-term complications of treatment, such as premature menopause, osteoporosis, secondary tumors, or cardiovascular diseases. During follow-up, further use of hormonal treatment should encourage, as with time, fear of cancer decreases and with it the motivation to use long-term treatment. Periodic follow-up visits should also include psychological and social counselling, which help in full recovery (11). Data acquired during follow-up visits can, in turn, be used for evaluating treatment outcomes in individual centers.

Based on current knowledge, the plan of follow-up assessments in women with breast cancer is dependent on the stage of the disease. In patients after palliative treatment, it is closely asso- 
ciated with treatment outcomes and should be tailored to individual patients. In the case of patients after radical treatment, international recommendations are available; for instance, the 2015 recommendations of the American Society of Clinical Oncology (ASCO) and European Society for Medical Oncology $(\mathrm{ESMO})(11,12)$.

Repeated and detailed physical examination is the basis for follow-up assessment. During the first 2 years after diagnosis, it should be conducted every 3-4 months; every 6 months for the subsequent 3 years, and every 12 months after 5 years since diagnosis (strength of recommendation V,A - Tab. I] (11). According to ASCO, more frequent follow-up visits should be conducted during the first 3 years, and then they should be performed every 6 months (12).

During a follow-up visit, patients should be encouraged to perform systematic, monthly self-examinations and learn the symptoms of recurrence. In that respect, it is important to inform patients of the genetic aspects of the disease, and order additional tests if necessary. Genetic testing and genetic counselling are recommended in the following situations: ovarian cancer in the patient or their first-order and second-order relatives, breast cancer before 50 years of age in one first-order relative or at least two cases in first-order or second-order relatives regardless of age at diagnosis, bilateral breast cancer in a family relative or breast cancer in a man (11). According to the recommendations issued by ASCO, genetic studies should also be performed in all patients with triple-negative breast cancer diagnosed before 60 years of age (12).

Recently, promotion of a healthy lifestyle, including physical activity, has become an important aspect of cancer surveillance [II,B], and in obese women dietary counselling is recommended to attain normal weight [III,B] $(14,15)$.

Patients should have unlimited access to physical therapy and other services that alleviate physical, psychological, and social consequences of breast cancer. The main aim of physical therapy, which has been extensively popularized, is prophylaxis of lymphatic edema, restoration of full motor function of the upper extremity, and correction of posture abnormalities that are seen after mastectomy.

During oncological follow-up, mammography should be performed once a year [II,A], and in patients who have been treated with breast-conserving therapy, first mammography should be performed 6 months after completion of radiation therapy. The recommendations of ASCO do not deal with routine use of ultrasound (US) examinations of the breasts, but ESMO recommends US assessments every 12 months [II,A], especially in the case of lobular cancer (11).

Magnetic resonance imaging (MRI) is not routinely recommended; however, it can be used in young women, patients with the so-called dense breasts, patients with BRCA1/2 or TP53 mutations $(16,17)$, or patients after reconstructive surgery. Also, MRI is the study of choice for loss of implant integrality (18).

An annual gynecological examination should also be an integral part of oncological follow-up. In patients with preserved uterus
Tab. II. Basic elements of follow-up for women after radical breast cancer treatment

\begin{tabular}{|ll}
\hline Recommended study & Frequency \\
\hline Brest self-exam (BSE) & Every month \\
\hline Physical examination & $\begin{array}{l}\text { first 2-3 years - every 3-4 months } \\
\text { 3-5 years - every } 6 \text { months } \\
>5 \text { years - every } 12 \text { months }\end{array}$ \\
\hline Mammography and breast US & every 12 months \\
\hline Gynecological examination & every 12 months \\
\hline Densitometry & every 12-24 months in patients with HT \\
\hline Body weight assessment & BMI 20-25 recommended \\
\hline $\begin{array}{l}\text { Additional imaging and } \\
\text { laboratory studies }\end{array}$ & Only due to medical reasons \\
\hline
\end{tabular}

who have been treated with adjuvant tamoxifen, gynecological examination should include transvaginal US because of an increased risk of endometrial cancer [V,A]. Only in patients with removed uteri can examination intervals be extended.

During treatment with aromatase inhibitors, periodic assessment of bone density is recommended along with supplementation of calcium and vitamin D3 [I,A]. One should pay attention to the increased risk of osteopenia in women over 65 years of age, smokers, patients with BMI below 18, alcohol abusers, and people with low physical activity. Current ASCO guidelines also recommend performing densitometry in patients who receive adjuvant treatment with tamoxifen and/or GnRH analogs and those who experience premature menopause due to chemotherapy. The time interval between studies should be 1-2 years and is determined based on individual osteopenia risk (12). Because of potential adverse effects of hormonal therapy, patients who receive that treatment should be assessed for blood lipids $\{\mathrm{V}, \mathrm{B}]$. According to ESMO guidelines, hormone replacement therapy is contraindicated as estrogen and progesterone significantly increase the risk of recurrence [I,A] (19). The most important elements of follow-up assessments in patients with breast cancer after radical treatment are summarized in Table II.

In asymptomatic patients, routine performance of additional laboratory or imaging studies is not indicated for seeking out distal metastases [I,A]. Measurement of cancer markers (CA15.3, CA27.29, CEA, CA-125, MUC-1), chest x-rays, abdominal ultrasound, bone scintigraphy, computed tomography, magnetic resonance imaging, or PET are spurious. Based on a multitude of studies, an earlier detection of systemic recurrence owing to an extended follow-up assessment does not influence treatment outcomes, survival, or quality of life (20-24).

Restrictions regarding the number of studies during oncological follow-up pertain only to asymptomatic patients. Obviously, if abnormal symptoms or sings are present, the necessary diagnostic workup should be ordered (11).

Perhaps, the program of follow-up assessments in patients after radical treatment of breast cancer will be changed; for instance, there might be different recommendations for patients with different molecular subtypes of cancer. In patients with breast cancers that have unfavorable prognosis, assessments with the use of modern imaging techniques such as PET-CT or PET-MRI could contribute to better outcomes. New prognostic 
and predictive factors are sought out, which could identify patients at an increased risk of recurrence. To date, 11 genes that increase the risk of recurrence are known, but practical use of this information is limited $(25,26)$.

Lastly, it should be mentioned that international recommendations allow that follow-up assessments be carried out by trained

\section{REFERENCES}

1. Brody H.: Medicine's ethical responsibility for health care reform-the top five list. N. Eng. J. Med. 2010; 362 (4): 283-285.

2. Schnipper L.E., Smith T.J., Raghavan D., et al.: American Society of Clinical Oncology identifies key opportunities to improve care and reduce costs: the top five list for oncology. J. Clin. Oncol. 2012; 30 (14): 1715-1724.

3. Foster J.A., Abdolrasulnia M., Doroodchi H., et al.: Practice patterns and guideline adherence of medical oncologists in managing patients with early breast cancer. J. Natl. Compr. Canc. Netw. 2009; 7 (7): 697-706.

4. Keating N.L., Landrum M.B., Guadagnoli E., et al.: Surveillance testing among survivors of early-stage breast cancer. J. Clin. Oncol. 2007; 25 (9): 1074-1081.

5. Panageas K.S., Sima C.S., Liberman L., et al.: Use of high technology imaging for surveillance of early stage breast cancer. Breast Cancer Res. Treat. $2012 ; 131$ (2): 663-670.

6. Wojciechowska U., Didkowska J., Zatoński W.: Nowotwory złośliwe w Polsce w 2012 roku. J. Oncology. 2013; 63 (3).

7. Allemani C., Minicozzi P., Berrino F., et al.: Predictions of survival up to 10 years after diagnosis for European women with breast cancer in 2000-2002. Int. J. Cancer. 2013; 132: 2404-2412.

8. Allemani C., Weir H.K., Carreira H., et al.: Global surveillance of cancer survival 1995-2009: analysis of individual data for 25,676,887 patients from 279 population-based registries in 67 countries (CONCORD-2). Lancet. 2015; 385: 977-1010.

9. Colleoni M., Sun Z., Price K.N., et al.: Annual hazard rates of recurrence for breast cancer during 24 years of follow-up: results from the International Breast Cancer Study Group Trials I to V. J. Clin. Oncol. 2016; 34 (6). http://jco.ascopubs.org/content/early/2016/01/14/JCO.2015.62.3504

10. Cheng L., Swartz M.D., Zhao H., et al.: Hazard of recurrence among women after primary breast cancer treatment-A 10-Year follow-up using data from SEER-Medicare. Cancer Epidemiol. Biomarkers Prev. 2012; 21 (5): 800-809.

11. Senkus E., Kyriakides S., Ohno S., et al.: Primary breast cancer: ESMO Clinical Practice Guidelines for diagnosis, treatment and follow-up. Ann. Oncol. 2015; 26 (suppl 5): v8-v30.

12. Runowicz C.D., Leach C.R., Henry N.L., et al.: American Cancer Society/American Society of Clinical Oncology breast cancer survivorship care guideline. J. Clin. Oncol. 2015; http://jco.ascopubs.org/content/early/2015/12/07/JCO.2015.64.3809

13. Dykewicz C.A. Summary of the guidelines for preventing opportunistic infections among hematopoietic stem cell transplant recipients. Clin. Infect. Dis. 2001; 33: 139-144.

14. Holmes M.D., Chen W.Y., Feskanich D., et al.: Physical activity and survival after breast cancer diagnosis. JAMA 2005; 293: 2479-2486.

15. Chlebowski R.T., Aiello E., McTiernan A.: Weight loss in breast cancer patient management. J. Clin. Oncol. 2002; 20: 1128-1143. family physicians 5 years after treatment, and in patients with low-stage breast cancer (tumor diameter $<5 \mathrm{~cm}$, fewer than 4 affected lymph nodes) 1 year after treatment (11). Studies carried out in different countries have shown that the efficacy of follow-up is comparable if performed by oncologists or family physicians (27-29). But can the Polish healthcare system adopt such solutions? Currently, the answer is no.

16. Jatala S., Fitzgerald S., Tietze P., et al.: What are the recommended timing and screening modalities in women at higher risk for developing breast cancer? A Clin-IQ. J. Patient Cent. Res. Rev. 2015; 2 (1): 38-42.

17. Saslow D., Boetes C., Burke W., et al.: American Cancer Society guidelines for breast screening with MRI as an adjunct to mammography. Cancer J. Clin. 2007; 57 (2): 75-89.

18. Rietjens M., Villa G., Toesca A., et al.: Appropriate use of magnetic resonance imaging and ultrasound to detect early silicone gel breast implant rupture in postmastectomy reconstruction. Plast. Reconstr. Surg. 2014; 134 (1): $13-20$.

19. Holmberg L., Iversen O.E., Rudenstam C.M., et al.: Increased risk of recurrence after hormone replacement therapy in breast cancer survivors. J. Natl. Cancer Inst. 2008; 100: 475-482.

20. Harris L., Fritsche H., Mennel R., et al.: American Society of Clinical Oncology 2007 update of recommendations for the use of tumor markers in breast cancer. J. Clin. Oncol. 2007; 25 (33): 5287-5312.

21. Carlson R.W., Allred D.C., Anderson B.O., et al.: Invasive breast cancer. J. Natl. Compr. Canc. Netw. 2011; 9 (2): 136-222.

22. Grunfeld E., Dhesy-Thind S., Levine M.: Clinical practice guidelines for the care and treatment of breast cancer: follow-up after treatment for breast cancer. CMAJ 2005; 172 (10): 1319-1320.

23. Rojas M.P., Telaro E., Russo A., et al.: Follow-up strategies for women treated for early breast cancer. Cochrane Database Syst. Rev. 2005 (1). http:// onlinelibrary.wiley.com/doi/10.1002/14651858.CD001768.pub2/full

24. Henry N.L., Hayes D.F., Ramsey S.D., et al.: Promoting quality and evidence-based care in early-stage breast cancer follow-up. J. Natl. Cancer Inst. 2014; 106 (4): 1-7.

25. Meric-Bernstam F., Frampton G., Ferrer-Lozano J., et al.: Concordance of genomic alterations between primary and recurrent breast cancer. Mol. Cancer Ther. 2014; 13 (5): 1382-1389.

26. Yates L., Knappskog S., Martincorena I., et al.: The driver landscape of breast cancer metastasis and relapse. European Cancer Congress; Vienna, Austria, 25-29 Sept. 2015: a1804. http://www.cancernetwork.com/articles/ top-highlights-2015-european-cancer-congress\#sthash.4KuDRbfs.dpuf

27. Boekhout A.H., Maunsell E., Pond G.R., et al.: A survivorship care plan for breast cancer survivors: Extended results of a randomized clinical trial. J. Cancer Surviv. 2015; 9 (4): 683-691.

28. Mao J.J., Bowman M.A., Stricker C.T., et al.: Delivery of survivorship care by primary care physicians: The perspective of breast cancer patients. J. Clin. Oncol. 2009; 27 (6): 933-938.

29. Grunfeld E., Levine M.N., Julian J.A., et al.: Randomized trial of long-term follow-up for early-stage breast cancer: A comparison of family physician versus specialist care. J. Clin. Oncol. 2006; 24 (6): 848-855. 


$\begin{array}{llll}\text { Word count: } 1600 \quad \text { Page count: } 4 \quad \text { Tables: } 2 & \text { Figures: }- & \text { References: } 29\end{array}$

DOI: $\quad 10.5604 / 01.3001 .0010 .1087$

Table of content: http://ppch.pl/resources/html/articlesList?issueld=9993

Copyright: Copyright @ 2017 Fundacja Polski Przegląd Chirurgiczny. Published by Index Copernicus Sp. z o. o. All rights reserved.

Competing interests: The authors declare that they have no competing interests.

The content of the journal "Polish Journal of Surgery" is circulated on the basis of the Open Access which means free and limitless access to scientific data.

\section{(c) (i) (2) (2)}

Corresponding author:

Cite this article as:

This material is available under the Creative Commons - Attribution 4.0 GB. The full terms of this license are available on: http://creativecommons.org/licenses/by-nc-sa/4.0/legalcode

dr med. Diana Hodorowicz-Zaniewska, I Katedra Chirurgii Ogólnej, Uniwersytet Jagielloński Collegium Medicum, Klinika Chirurgii Ogólnej, Onkologicznej i Gastroenterologicznej, ul. Kopernika 40, 31-501 Kraków; tel.+48 1242480 95, e-mail: dianahz@poczta.onet.pl

Hodorowicz-Zaniewska D., Herman K.; Principles of follow-up assessments in patients with breast cancer after radical treatment; Pol Przegl Chir 2017: 89 (3): 36-39 